Article

\title{
Contributions of Urban Collective Gardens to Local Sustainability in Mexico City
}

\author{
Karla Guzmán Fernández ${ }^{1}$, Ana I. Moreno-Calles ${ }^{1, * \mathbb{C}}$, Alejandro Casas ${ }^{2}\left(\mathbb{D}\right.$ ) and José Blancas ${ }^{3}(\mathbb{D}$ \\ 1 Escuela Nacional de Estudios Superiores (ENES), Universidad Nacional Autónoma de México, \\ Antigua Carretera a Pátzcuaro 8701, Morelia 58190, Michoacán, Mexico; fernandezguzmankarla@gmail.com \\ 2 Instituto de Investigaciones en Ecosistemas y Sustentabilidad. Universidad Nacional Autónoma de México, \\ Antigua Carretera a Pátzcuaro 8701, Morelia 58190, Michoacán, Mexico; acasas@cieco.unam.mx \\ 3 Centro de Investigación en Biodiversidad y Conservación, Universidad Autónoma del Estado de Morelos, \\ Avenida Universidad 1001, Colonia Chamilpa, Cuernavaca 62209, Morelos, Mexico; jose.blancas@uaem.mx \\ * Correspondence: isabel_moreno@enesmorelia.unam.mx
}

Received: 15 August 2020; Accepted: 10 September 2020; Published: 14 September 2020

check for updates

\begin{abstract}
Urban collective gardens (UCG) are considered alternatives to face the environmental problems generated by urbanization, contributing to the sustainability of cities. This study aims to characterize UCG and its contributions to the local sustainability in Mexico City (CdMx). From bibliographic searches, consultation on social networks, and expert suggestions, our research group identified 40 gardens for CdMx, based on which we constructed a UCG typology. For deeper studies, we selected 19 UCGs based on several criteria: Number of members (at least three persons managing UCG), UCG age (at least one year), disposition of collaborating in the study, and availability for evaluation. The selected UCGs were evaluated qualitatively following the Framework for the Evaluation of Natural Resource Management Systems incorporating Sustainability Indicators (MESMIS, for its acronym in Spanish) through in-depth interviews and participant observation. We identified critical points or factors that drive or limit UCG (e.g., biological diversity, training of people participating, social and economic stability, access to space and financial support, economic diversification, input dependency, security of land tenure, and contamination risk). We concluded that UCG of CdMX contribute to local sustainability through processes like creating jobs, recovering connections with nature, knowledge transmission, experimental practices, and offers of therapeutic benefits, among others.
\end{abstract}

Keywords: urban agriculture; MESMIS; resilience; Latin American cities

\section{Introduction}

Cities are relevant for the social and economic activities, but their operation has high environmental impacts [1]. Urban areas produce large amounts of waste, dramatically modify flora and fauna, create islands of heat, alter soils and different natural cycles including water and carbon, contaminate the atmosphere, and generate environments highly propitious to the spread of infectious diseases [2-6]. The rapid growth of global urbanization and urban population increase will aggravate these situations within a short time $[7,8]$. All these problems make it a high priority to study the sustainability conditions of cities [9], the influence of urbanization on sectors operating there (transport, housing, energy, food, health), and the routes to achieve better conditions. There is no consensus about the ideal characteristics that a sustainable city should have; but Jenks and Jones (2010) [10], among others, state that the presence of public green areas, waste management, activities that promote social satisfaction and the perception of well-being, and the maintenance of sustainable consumption habits, among others, are crucial [10-12]. 
Urbanization causes a disconnection between people and the origin of their food [13-17], this implies that urban inhabitants do not know where it comes from, how it is produced, under what conditions, and the implications for people that provide it [18]. This form of relationship between food production and consumption has promoted a sharp division between nature and culture in urban areas. It decreases commitment to natural areas, productive spaces in cities, and people who oversee this work. Such distancing favors a higher generation of organic waste, increase of food prices in these places, the loss of knowledge and practices related to the processes that produce them, food poverty, and contributes to affecting human health, since contact with nature promotes well-being $[17,19,20]$.

Urban agricultural practices (UAP) contribute to the sustainability of a city due to benefits such as biodiversity conservation, waste management, social interaction, knowledge exchange, strengthening food security, and local economy $[3,16,21,22]$. In addition, UAP promote educational spaces, recovering connections with nature, and access to healthy food [16,17], reduce stress, and increase emotions of affection and joy and feelings of belonging and collaboration when these are carried out collectively $[14,16,19,20,23-31]$. Among the UAP, the urban collective gardens (UCG) are outstanding systems. These are spaces in the cities directed to cultivate food, ornamental, and medicinal plants, among other useful plants. Production of UCG may be for direct consumption or commercialization, and these systems are mostly public in terms of ownership, access, and decision-making, although these may also be private. UCGs are managed collectively, either by a group of individuals or households with common goals, activities, and interests, where social relationships occur that provoke everyday work and a sense of belonging. Finally, and although not strictly, most UCGs are based on agroecological practices or permaculture philosophies [3,4,32-39].

Processes necessary to obtain UCG benefits, their sustainability, as well as the impact on sustainability of cities, have been little studied [31,40-43]. At the national and international levels, there are few studies on the relationship between UCGs and the sustainability of cities; the few available are generally descriptive and do not address the different dimensions of sustainability comprehensively [26,28]. Particularly for Mexico City (CdMx), research has been mainly directed to document UAP systems in peri-urban areas, such as family gardens and chinampas, which have been present in the city since pre-Hispanic times [44,45].

The first UCG started in 2007, created by civil associations, neighborhood organizations, and non-governmental organizations, some of them with government or private foundations' financial support [46]. Between 2007 and 2012, the Ministry of Rural Development and Equity for Communities (SEDEREC) of Mexico City invested nearly USD 6 million in 2800 to promote UCG projects and family gardens [46]. UCGs are relatively new systems in CdMx, but it is interesting to know and understand the possibilities of their permanence and the role they may play to contribute to sustainability of CDMX and other cities.

The objective of this study is to evaluate the sustainability of UCG in CdMx and their adjustments and potential contributions they may give to local sustainability. The study characterized the variation of UCG and defined pertinent sustainability indicators for analyzing and improving these systems. We analyzed the actual and potential contributions towards sustainability of localities of the city. We based our study following the Framework for the Evaluation of Natural Resources Management Systems incorporating Sustainability Indicators (MESMIS for its acronym in Spanish) mainly using a qualitative approach [47-50]. We aspire that the information from this study could be useful to analyze the conditions necessary to reinforce and improve the existing experiences, contribute recommendations to local UCG managers, and to provide information for future similar research projects.

\section{Study Area and Methodology}

\subsection{Mexico City}

Mexico City (CdMx) is settled in the Valley of México (Figure 1), at $2428 \mathrm{~m}$ above sea level, with $9600 \mathrm{~km}^{2}$ extent, surrounded by a volcanic mountain range. The climate is temperate with rains in 
summer; the average temperature is between 18 and $24^{\circ} \mathrm{C}$, the average annual precipitation between $1000 \mathrm{~mm}$ and $1400 \mathrm{~mm}$ [51].

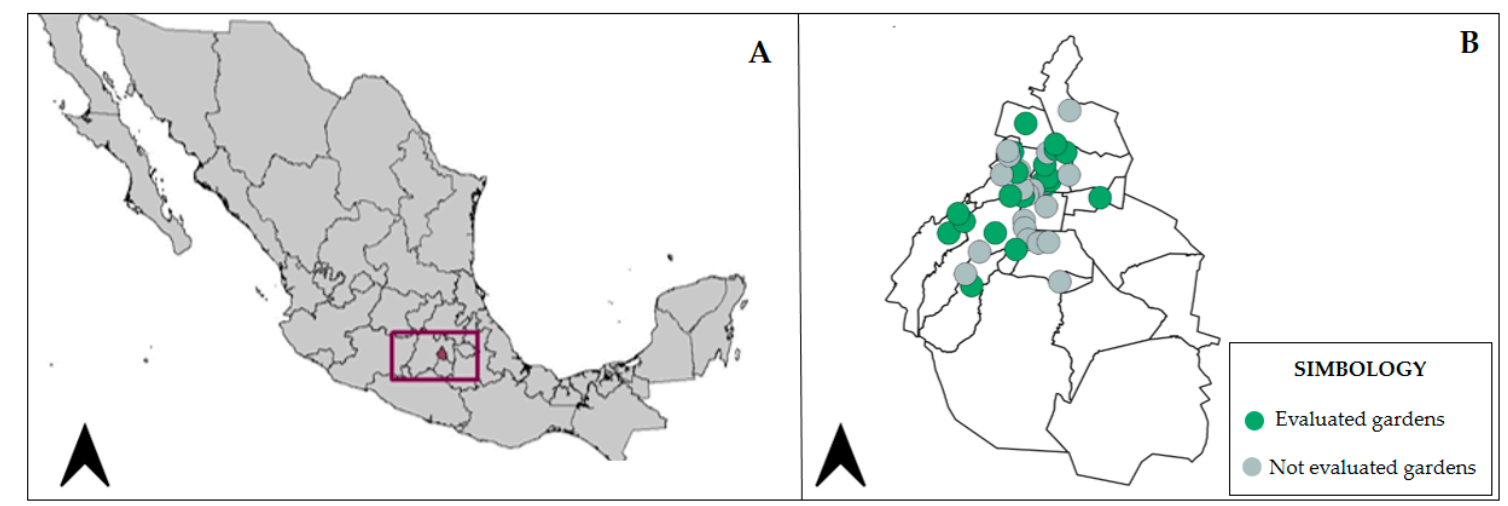

Figure 1. (A) Mexico City. (B) Geographic location of the urban collective gardens (UCG) studied. The green points indicate the gardens where interviews were carried out.

The National Population Council (CONAPO) estimated that in 2017, in CdMx and its metropolitan area, there were around 21 million people, making it one of the largest megalopolises in the world [51,52]. According to the 2015 intercensal survey, of the total employed people, only $0.39 \%$ worked in the agricultural sector [53]. UAP are still incipient activities; however, relevant UCG experiences have emerged (Figure 1), which have been managed by various social actors, mainly civil associations, non-governmental organizations, and neighborhood groups [46].

\subsection{Urban Agriculture in Mexico City}

The primary agricultural practices that existed in the Valley of Mexico since pre-Hispanic times were the chinampas, the slash, tomb and burn, slash, and burn systems, terraces, home gardens, and backyards [44]. Later, during the construction and consolidation of Mexico City, the political-administrative changes, the introduction of activities such as mining, deforestation, and the draining of the lake where the city was settled negatively impacted the agricultural systems that sustained people of the area for centuries [44]. Conversion of some forms of traditional agriculture into permanent agriculture took place throughout this process $[44,45]$.

In the first half of the 19th century, the inhabitants of Mexico City obtained their food mainly from three agricultural areas of the Valley of Mexico: The northern and western areas (maize, wheat, livestock); the eastern zone (maize, fruit, agaves); and the southern region (vegetables, meat, milk, Opuntia prickle pears, agaves) [44]. During the industrialization enhancing policy (1960-1990), a process of expropriation of land for the construction of houses and public services took place [45]. This process was intensified by the high rate of population immigration from rural areas to work in factories, which increased pressure for urbanization and, in turn, raised the price of land, which motivated many people to sell their properties and abandon agriculture [45]. People progressively reduced their land destined to production areas, and today these areas are residential and industrial spaces, which correspond to Mexico City and its Metropolitan area [51,54].

In 1970, there was a reclassification of the city into areas called "urban" and "agricultural". Of the total of municipalities (16), only seven have agricultural areas [44]. Currently, the traditional UAP in Mexico City only persists in some municipalities, such as the cases of Tlalpan, Milpa Alta, Tláhuac, and Xochimilco, mainly in the peripheral areas of the City [45].

In 2007, the government of Mexico City created the Secretary of Rural Development and Equity for Communities (SEDEREC for its acronym in Spanish), which between that year and 2012, invested around USD 6 million to promote 2800 organic agriculture projects, including UCG and family gardens [46]. In 2013, the SEDEREC, together with the Institute of Fundamental Research in Tropical Agriculture 
of Cuba, started a program to develop UAP in the Álvaro Obregón, Cuauhtémoc, Miguel Hidalgo, and Cuajimalpa municipalities Parallelly, the Ministry of Urban Development and Housing of Mexico City (SEDUVI) promoted the installation of orchards on roofs $[46,54,55]$.

The civil society has had an essential role promoting initiatives of significant impact in the city. These have been products of work of civil associations, neighborhood organizations, and non-governmental organizations, which led to generating UCG projects, sometimes with government or private foundation financial support [46]. In 2008, some experiences with community gardens started, and then a Law on Urban Gardens was decreed in 2016 [46,56]. The main objective of this law is to promote local production, fair trade, sustainable agriculture, and acceptable UAP [57].

\subsection{Methodology}

We integrated a characterization section following the method of the Framework for the Evaluation of Natural Resource Management Systems incorporating Sustainability Indicators (MESMIS) [47-50]. According to MESMIS, sustainability is defined as the maintenance of desired objectives or properties of systems (either productive, natural, or social-ecological) throughout time. Ecological, social, and economic dimensions are included in this definition. The base of evaluation of sustainability through this framework's methodology is the definition of seven attributes crucial to analyze the long-term permanence of systems: Productivity, stability, resilience, reliability, adaptability, equity, and autonomy [50]. These attributes in scientific literature are related to the sustainability of management systems [47-50]. These seven attributes, according to MESMIS, refer to the system's ability to remain stable over time, to be resistant to external shocks, or recovering from their effects, to its ability to provide goods and services to the manager of a system, to distribute the products fairly, as well as to be able to regulate its interactions with the outside. For the purposes of this research, this methodology was chosen because of its flexibility to adapt to different contexts and to analyze different types of systems; also, because of its comprehensive vision of sustainability. To make operative the analysis of these attributes, this methodology proposes the identification of critical points, that is, those factors that drive or limit the system analyzed, which are subsequently evaluated through specific indicators and methods [47-50].

\subsubsection{Identification of the Study System}

Theoretical Sampling

We searched bibliographic information about UCG. We reviewed the Google Academic search engine and the Scopus database. Subsequently, other sources of information included theses repositories from different universities, conference proceedings, as well as popular publications of civil associations. The search was carried out in Spanish and English using the following keywords: "Urban agriculture", "urban gardens", "community gardens", "school gardens", "agroecological gardens", "university gardens", "ecological gardens", and "Mexico". Consequently, we searched on social networks (Facebook) usually used to disseminate this type of project [58]. We consulted experts, and selected Mexico City since it has the highest number of UCG. Finally, we identified some gardens during the application of interviews. We followed a snowball method, interviewing a UCG manager to whom we asked to suggest other orchards managers [59].

For the selection of the experiences to study, we defined the following criteria: (i) That urban gardens were collective, in the literature we did not find a minimum number, but in the experiences registered, the minimum number of persons participating was three; (ii) the project was at least one-year-old, as the authors reported in the literature as an adequate period to observe changes [60] and, (iii) the willingness of the members of the garden to participate in this research. We found a total of 40 UCG in CdMx that met the criteria and evaluated 19, according to our possibilities. We employed theoretical sampling, which "is not predetermined before the investigation begins but evolves during the process" [61]. In other words, we did fieldwork simultaneously with the evaluation 
of the information obtained, up to the point of theoretical saturation (Figure 2) [62]. We decided to stop the application of interviews, resulting in the assessment of 19 UCG.

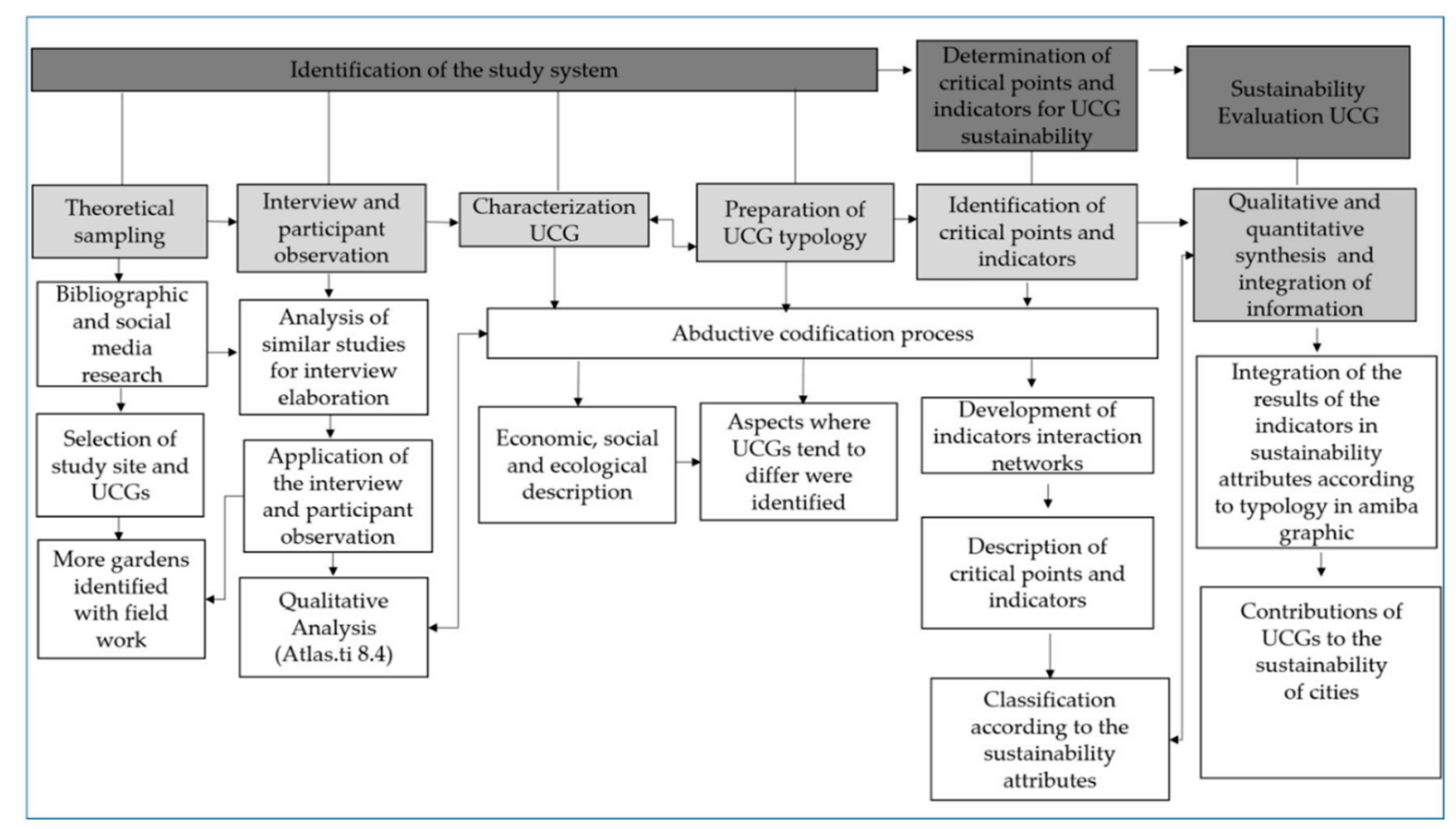

Figure 2. Methodological sequence carried out in our study. A qualitative approach of the chosen methodology (MESMIS) was used [47-50]. To illustrate the above, the steps established by the MESMIS are mentioned in the first line of the diagram; the second line shows the methods used to fulfill the steps of the MESMIS; finally, the specific steps that were followed for each of the phases of the investigation are indicated in the white boxes. The methodological process includes the identification of the system to be evaluated, the determination of critical points and indicators for the sustainability of the UCGs, and the evaluation of the sustainability of the UCGs and their contributions to the city.

In-Depth Interview, Participant Observation, and Analysis

The in-depth semi-structured interview was prepared from an analysis of previous research in the design and application of indicators to assess the sustainability of UAP and UCG [63]. The topics covered in the interviews were the following: The history of experiences, description of organization and activities, characterization of management practices, limitations, and opportunities of the project. We interviewed the managers of each UCG who agreed to participate (19 interviews of 45 min to $2.5 \mathrm{~h}$ ). The participant observation [64], together with the application of interviews, were carried out from December 2018 to April 2019. The visit period of the UCGs was from 1 to 14 days, depending on the accessibility of the members of the gardens, as well as their location, as some are in places of difficult access. The time of the visits was from two to six hours, in which different members of the UCG participated, mainly those directly involved with the maintenance of the crops, as well as with the volunteers. The activities carried out were: Guided tours, participation in daily maintenance activities (harvest, weeding, seed collection, harvest sale, food preparation), informal talks with visitors or volunteers, as well as participation in events organized by gardens managers. Subsequently, we transcribed the interviews and observations. We analyzed boot using the qualitative analysis software Atlas.ti 8.4 [65]. We performed abductive coding (interaction between inductive and deductive codification process).

\section{Characterization System and UCGs Typology}

We classified the codes into two groups; the first refers to those related to the ecological, economic, and social characterization of the study system. We delved into the characterization of 
UCGs by developing a typology. We began defining it based on the aspects in which the UCG tend to differ according to the literature: Type of management, garden objectives, land tenure, organization, and accessibility to the garden $[4,46,66,67]$. We developed the typology according to the type of management promotion agency, and four categories were derived: Civil association, government, business, and private institution.

The second stage delved into those relevant elements or processes to analyze the sustainability of the UCG and their contributions to local sustainability (benefits generated, risk factors, permanence over time). We classified the resulting categories according to the sustainability attributes defined by MESMIS [47-50].

\subsubsection{Identification of Critical Points, Indicators, and Sustainability Evaluation}

We obtained critical points in an abductive way, based on information, from the point of view of the UCG managers, participant observation, and from literature review. From the critical points, we defined the most relevant indicators, and these were related with sustainability attributes to evaluate sustainability of the UCG studied. The evaluation of indicators was made from the analysis of the interviews and participant observation. The first step was assigning codes or labels to what the interviewees mentioned in relation to UCG, and then classifying this information by topics related to each attribute. The above allowed us to visualize what different people mentioned on the same topic. Subsequently, a network was developed in which interactions were established between the generated codes, which are also based on what was mentioned by people in the interviews, participant observation, and literature review. This network allowed a general understanding of the UCG as system. Additionally, from the network, it was possible to identify critical points for the sustainability of the UCGs, that is, factors that drive or limit the level of sustainability. For this purpose, we considered that the critical points were identified in at least half of the gardens evaluated. Subsequently, from the critical points, the indicators to evaluate were derived. A bibliographic review of indicators used in similar investigations was performed, and then we adapted our own observations and results from interviews to the critical points resulting from this study. The next step was to evaluate the indicators from the interviews and participant observation. For instance, the indicator of biological diversity was evaluated from the species mentioned by the interviewees in the tours. This was carried out for the 19 gardens, and afterwards the results were averaged by category (civil association, government, company, and private institution). Since quantitative and qualitative indicators were obtained, the last step was to unify the results on a scale from 0 to 100 following the methods explained in Table 1 . We expressed the qualitative values in low, medium, and high. These levels were established based on what was recorded from the interviewees (Table 1):

Table 1. Methods employed for indicators integration.

\begin{tabular}{|c|c|}
\hline Indicators & Methods \\
\hline Perceived benefits & \multirow{3}{*}{$\begin{array}{l}\text { We identified the maximum number (of each indicator) in the total of } \\
\text { the UCG that was taken as the full value }(100 \%) \text {. We obtained that } \\
\text { reference value, with the percentage obtained by each category. }\end{array}$} \\
\hline Activities diversification & \\
\hline Ecotechnology & \\
\hline Permanence time of the participants & \multirow{3}{*}{$\begin{array}{l}\text { We evaluated these indicators out qualitatively. We established three } \\
\text { levels of the evaluation (low, medium, high), and we determined } \\
\text { based on the interviews. Subsequently, we assigned the following } \\
\text { numerical values to each of the levels: Low } 0-33 \% \text {, medium 33-66\%, } \\
\text { high } 66-100 \% \text { [48]. }\end{array}$} \\
\hline $\begin{array}{l}\text { Generation and transmission of } \\
\text { knowledge }\end{array}$ & \\
\hline Land tenure security & \\
\hline Biological diversity & $\begin{array}{l}\text { We established the maximum number of species identified in a UCG } \\
\text { (65 species) was the maximum value }(100 \%) \text {. We built the maximum } \\
\text { value concerning the percentage by category. }\end{array}$ \\
\hline
\end{tabular}


Table 1. Cont.

\begin{tabular}{cc}
\hline Indicators & Methods \\
\hline $\begin{array}{c}\text { Accessibility (space, people diversity, } \\
\text { economic) }\end{array}$ & $\begin{array}{c}\text { We assigned qualitative values (low, medium, high) for these } \\
\text { indicators. We established values for the sub-indicators, and then } \\
\text { they were averaged. }\end{array}$ \\
\hline $\begin{array}{c}\text { Supplies independence (water, seeds, } \\
\text { Sertilization, plague management) }\end{array}$ & $\begin{array}{c}\text { We based the evaluation of this indicator on the presence of the two } \\
\text { identified risk factors. Not having either of these two factors was } \\
\text { established as } 100 \%, \text { having one as } 50 \%, \text { and having both as } 0 \% .\end{array}$ \\
\hline
\end{tabular}

\section{Results}

\subsection{Urban Collective Gardens: Tipology and Characterization}

We defined the UCG of Mexico City as the study system. The systems analyzed have socioeconomic, ecological, and technological components. Socioeconomic component refers to the people who are full time in the gardens (employees and volunteers), for example, the coordinators, those in charge of maintenance of the garden, or those who give support in workshops and tours. We recorded between three and six full-time people per UCG. We interviewed seven men and 12 women, aging 22 to 66 years. Most people have university training (biology, agroecology, permaculture, agronomy, architecture, cinematography, and photography). The teaching and learning processes are important in the social component, that is, all the workshops, courses, diplomas, training, and tours in the UCG. These cover different topics on urban agriculture, among which are the following: Compost, seed germination, transplantation, care that crops require (pest management, for example). Less frequent are cooking workshops or production of harvest products. Depending on the type of garden management, the workshops are offered free or at some cost. Some gardens dedicate especially to boys and girls. Less common are social service and volunteering. Some gardens include volunteer programs since people learn by working directly with the garden. In the same way, it happens with people who carry out their social service in these spaces; in this case, there is a two-way exchange of teaching and learning.

Ecological components refer to the main crops registered. UCG evaluated include polycultures and carried out agroecological practices, such as crop rotation and association. The selection of species within gardens depends on several factors, such as personal taste, ease of maintenance, customer demand, or the fulfillment of a specific function within the garden (for example, attracting pollinators). Some UCG decide to maintain species (mainly fruit trees) that were already in the space before the implementation of this. We identified fruit trees, vegetables, and medicinal plants. The most common species are Lactuca sativa (lettuce), Capsicum annuum (chilli peppers), Beta vulgaris var. cicla (chard), Mentha piperina (mint), Solanum lycopersicum (tomato), Allium cepa (onion), Allium sativum (garlic), Fragaria sp. (strawberry), Lavandula sp. (lavender). This component varies depending on the available space. The different gardens grow their crops in beds on the ground, in containers, or raised beds, and often reuse materials for their preparation.

The technological component refers to the devices that make specific processes more efficient. For example, for fertilization, compost, vermicompost, or mulch are used. UCG people manage pests and diseases trough biological control, the selection and arrangement of species, natural mixtures, as well as physical traps. They control weeds with tezontle (red gravel incorporated into the substrate), mulching, or manual weeding. Within this subsystem, there are also eco-technologies. For example, rainwater harvesting systems, which increase independence towards the water resource, or dry toilets, biofilters, and compost, which allow treating a waste.

The interactions with the outside of the system are economic, social, and ecological. External communications are those that go from within the system to the outside. Examples are some type of collaboration with a company or the government, or if the garden to supplying inputs to other 
UCG. The so-called external contributions are the interactions that come from outside the system, for example, visitors and volunteers or material and financial donations. The main differences between categories are in the interactions they have with the outside world (Appendix A).

We obtained four types of UCG based on management agencies: Civil associations, government, companies, and private institutions (Figure 3). We found differences between these types of gardens in general characteristics such as the objectives of the gardens, kind of land tenure, accessibility, and form of organization or participation. We identified two types of accessibility (public and private); seven different objectives among the UCG studied (social integration, education, and transmission of knowledge, add value, showroom, production, recovery or appropriation of public spaces, promoting environmental issues); two types of land tenure (ceded by the government or private property); and three forms of organization or participation (employment, volunteering, or scholar). Each management category has one or two predominant objectives. In Table 2, we show how accessibility, goals, land tenure, and organization and participation vary in each type of garden.

Table 2. General characteristics and percentage of gardens by type.

\begin{tabular}{|c|c|c|c|c|c|}
\hline $\begin{array}{c}\text { General } \\
\text { Characteristics }\end{array}$ & $\begin{array}{c}\text { Particular } \\
\text { Characteristics }\end{array}$ & $\begin{array}{c}\text { Civil } \\
\text { Association (\%) }\end{array}$ & $\begin{array}{c}\text { Governmental } \\
(\%)\end{array}$ & $\begin{array}{c}\text { Company } \\
(\%)\end{array}$ & $\begin{array}{c}\text { Private } \\
\text { Institution (\%) }\end{array}$ \\
\hline \multirow{2}{*}{ Accessibility } & Public & 100 & 100 & 0 & 25 \\
\hline & Private & 0 & 0 & 100 & 75 \\
\hline \multirow{7}{*}{ UCG objective } & Social integration & 25 & 25 & 42 & 50 \\
\hline & $\begin{array}{c}\text { Education/ } \\
\text { transmission of } \\
\text { knowledge }\end{array}$ & 50 & 100 & 42 & 50 \\
\hline & Add value & 0 & 0 & 14 & 50 \\
\hline & Showroom ${ }^{a}$ & 0 & 0 & 86 & 0 \\
\hline & Production & 0 & 0 & 43 & 0 \\
\hline & $\begin{array}{l}\text { Recovery or } \\
\text { appropriation of } \\
\text { public spaces }\end{array}$ & 75 & 50 & 0 & 0 \\
\hline & $\begin{array}{c}\text { Promoting } \\
\text { environmental } \\
\text { issues }\end{array}$ & 75 & 50 & 43 & 25 \\
\hline \multirow[t]{2}{*}{ Land tenure } & $\begin{array}{l}\text { Ceded by the } \\
\text { government }\end{array}$ & 100 & 100 & 0 & 0 \\
\hline & Private property & 0 & 0 & 100 & 100 \\
\hline \multirow{3}{*}{$\begin{array}{l}\text { Organization/ } \\
\text { participation }\end{array}$} & Employment & 75 & 100 & 100 & 75 \\
\hline & Volunteering & 100 & 75 & 14 & 25 \\
\hline & Scholar & 0 & 0 & 0 & 50 \\
\hline
\end{tabular}

${ }^{a}$ Refers to UCG used as demonstration spaces for the services offered by companies.

Appendix A shows the UCG belonging to each category with some of their essential characteristics (starting date, location, approximate size, and historical description). The oldest gardens studied began in 2007, and the most recent started in 2018, increasing from the last decade (2010-2020). Three of the UCGs managed by civil associations arose on land that was damaged by the 1985 earthquake or was abandoned and used as garbage dumps. The UCG range in size from $62 \mathrm{~m}^{2}$ to 3.5 hectares, the above related to their location and the spatial availability of the City. Often the largest are managed by civil associations and governments. Figure 3 shows images obtained during field work; each photograph corresponds to an orchard of a different category. 

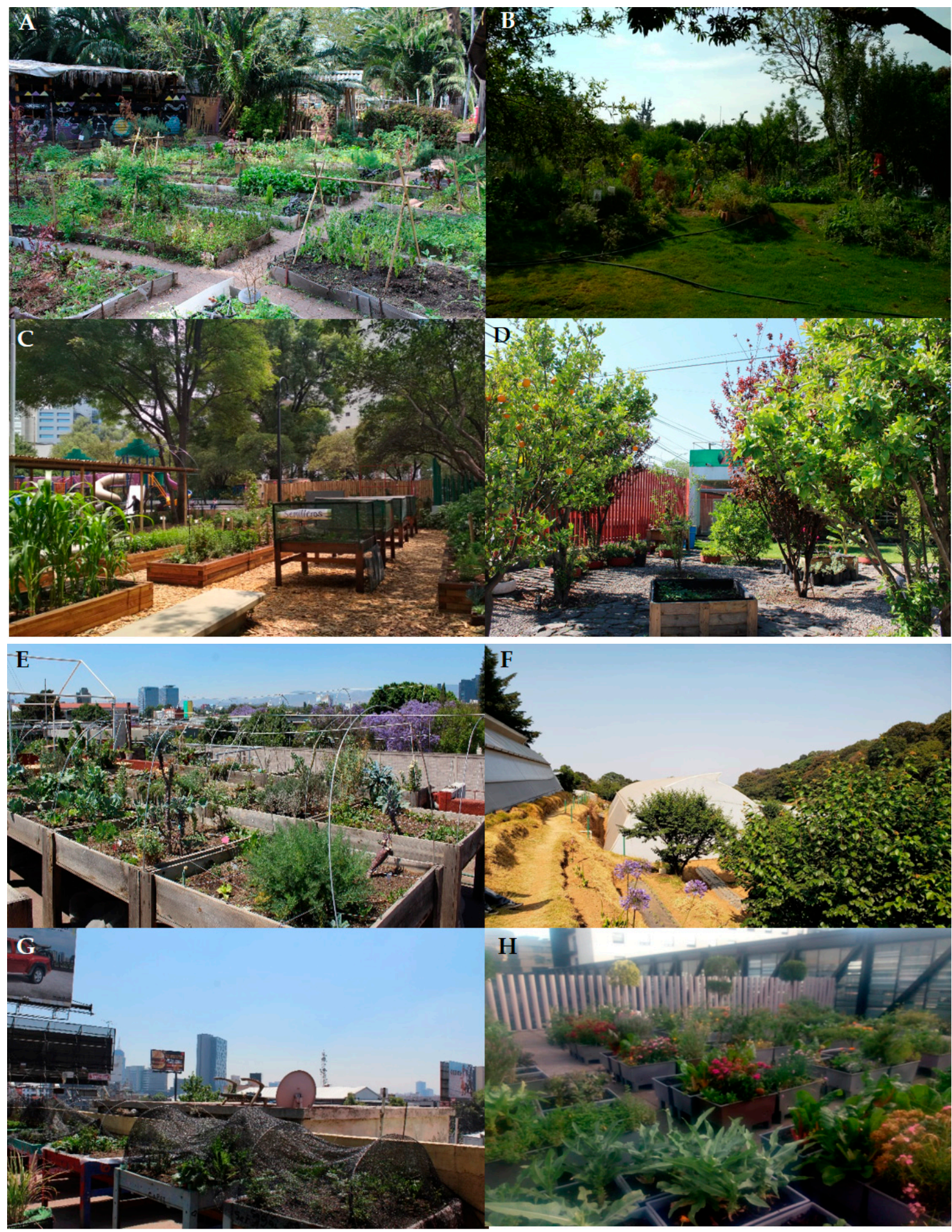

Figure 3. Collective gardens of Mexico City. (A) Huerto Roma Verde (civil association), crop beds made of recycled materials. (B) Huerto Tlatelolco (civil association), fruit trees and crops. (C). Huerto Lincoln (governmental), crop beds of different heights; in the background it can be seen where the children's area of the park is located. (D) Centro Verde Azcapotzalco (governmental), crops in containers and fruit trees. (E) ISLA (company), rooftop garden, raised beds. (F) Huerto los Cedros (company), crop beds, greenhouses, and fruit trees. (G) Huerto Fundación San Felipe (private institution), rooftop gardens, raised beds. (H) Huerto Hospital ABC Observatorio (private institution), crops in containers. 


\subsection{Critical Points and Indicators}

We identified ten critical points of the UCG, seven related to benefits, and three related to factors affecting the system. The benefits include the contributions of the UCGs, the commitment, and permanence of the participants, the high biological diversity that these systems maintain, the high stability and economic diversity that they promote, frequent training, the excellent accessibility to these spaces, and the high independence. Of inputs concerning other productive systems in CdMx. The negatives refer to the insecurity in land tenure, and therefore, to the permanence in these spaces and the continuity of the projects, the low technological diversification related to the little use of diverse eco-technologies, and a high risk of contamination of the species produced due to the location of the experiences in Mexico City or due to its proximity to busy avenues or garbage dumps.

From the critical points, we derive the indicators for each sustainability attribute. We identified, for productivity attribute, an indicator of perceived benefits. In the stability, reliability, and resilience attributes, we recognize the indicators of the time of permanence of the participants, the biological diversity, land tenure security, and diversification of activities. We proposed two indicators for the adaptability attribute, which are present eco-technologies and generation, and transmission of knowledge. For the equity attribute, the accessibility indicator (space, people diversity, economic) is shown. Finally, for the self-dependence attribute, two indicators were identified that are supplies independence and safety practices. Table 3 shows the sustainability attribute to which each critical point is associated, as well as its indicator. In the same table, the unit of measurement of each indicator can be consulted, as well as the method with which it was measured and the evaluation area to which it corresponds (ecological, economic, and social).

Table 3. Attributes, critical points, and indicators of sustainability (ecologic, economic, health, and social). Method of measurement: 1. Interview, 2. field verification. Evaluation Area: Ec: Ecologic, En: Economic, So: Social, He: Health.

\begin{tabular}{|c|c|c|c|c|c|}
\hline Attribute & Critical Points & Indicators & Units & $\begin{array}{c}\text { Method of } \\
\text { Measurement }\end{array}$ & $\begin{array}{c}\text { Evaluation } \\
\text { Area }\end{array}$ \\
\hline Productivity & $\begin{array}{l}\text { Multiple } \\
\text { benefits }\end{array}$ & $\begin{array}{l}\text { Perceived } \\
\text { benefits }\end{array}$ & $\begin{array}{l}\% \text { of total } \\
\text { profits } \\
\text { identified }\end{array}$ & 1 & $\mathrm{He}$, So, Ec, En \\
\hline \multirow{4}{*}{$\begin{array}{l}\text { Stability, reliability, } \\
\text { and resilience }\end{array}$} & Low dropout & $\begin{array}{l}\text { Permanence } \\
\text { time of the } \\
\text { participants }\end{array}$ & $\begin{array}{l}\text { Small, medium, } \\
\text { high }\end{array}$ & 1 & So \\
\hline & High diversity & $\begin{array}{l}\text { Biological } \\
\text { diversity }\end{array}$ & $\begin{array}{l}\text { Number of } \\
\text { species } \\
\text { managed }\end{array}$ & 1,2 & Ec \\
\hline & $\begin{array}{l}\text { Land tenure } \\
\text { security }\end{array}$ & $\begin{array}{l}\text { Land tenure } \\
\text { security }\end{array}$ & $\begin{array}{l}\text { Low, medium, } \\
\text { high }\end{array}$ & 1 & So \\
\hline & $\begin{array}{l}\text { High economic } \\
\text { stability }\end{array}$ & $\begin{array}{c}\text { Activities } \\
\text { diversification }\end{array}$ & $\begin{array}{c}\% \text { of the } \\
\text { activities } \\
\text { carried out } \\
\text { concerning the } \\
\text { total }\end{array}$ & 1 & En \\
\hline \multirow{2}{*}{ Adaptability } & $\begin{array}{c}\text { Low } \\
\text { technological } \\
\text { diversification }\end{array}$ & $\begin{array}{c}\text { Present } \\
\text { eco-technologies }\end{array}$ & $\begin{array}{l}\% \text { of present } \\
\text { eco-technologies } \\
\text { for the total }\end{array}$ & 1,2 & Ec \\
\hline & High training & $\begin{array}{l}\text { Generation and } \\
\text { transmission of } \\
\text { knowledge }\end{array}$ & $\begin{array}{l}\text { Low, medium, } \\
\text { high }\end{array}$ & 1 & So \\
\hline
\end{tabular}


Table 3. Cont.

\begin{tabular}{|c|c|c|c|c|c|}
\hline Attribute & Critical Points & Indicators & Units & $\begin{array}{c}\text { Method of } \\
\text { Measurement }\end{array}$ & $\begin{array}{c}\text { Evaluation } \\
\text { Area }\end{array}$ \\
\hline Equity & $\begin{array}{l}\text { High } \\
\text { accessibility }\end{array}$ & $\begin{array}{c}\text { Accessibility } \\
\text { (space, people } \\
\text { diversity, } \\
\text { economic) }\end{array}$ & $\begin{array}{l}\text { Low, medium, } \\
\text { high }\end{array}$ & 1,2 & So \\
\hline \multirow{2}{*}{$\begin{array}{l}\text { Self-dependence } \\
\text { (self-management) }\end{array}$} & $\begin{array}{l}\text { High supply } \\
\text { independence }\end{array}$ & $\begin{array}{c}\text { Supplies } \\
\text { independence }\end{array}$ & $\begin{array}{l}\text { Low, medium, } \\
\text { high }\end{array}$ & 1 & En \\
\hline & $\begin{array}{c}\text { High risk of } \\
\text { contamination }\end{array}$ & Safety practices & $\begin{array}{c}\% \text { of risk factors } \\
\text { to the total }\end{array}$ & 1,2 & $\mathrm{He}$ \\
\hline
\end{tabular}

\subsection{Evaluation of Indicators and Results Integration}

The indicator of identified benefits included the following nine categories: Incorporation of green areas, reconnection with nature, social interaction, awareness, diversification of diet, relaxation or reduction of stress, obtaining healthy products, and generating employment (Table 4).

Table 4. Indicator evaluation. (a) Maximum value found in the total of the gardens; (b) maximum value of a single garden.

\begin{tabular}{|c|c|c|c|c|c|}
\hline \multirow{2}{*}{ Indicators } & \multicolumn{5}{|c|}{ UCG Types } \\
\hline & $\begin{array}{c}\text { Civil } \\
\text { Association }\end{array}$ & Governmental & Company & $\begin{array}{c}\text { Private } \\
\text { Institution }\end{array}$ & $\begin{array}{l}\text { Maximum } \\
\text { Value }\end{array}$ \\
\hline Identified benefits & 8 & 6 & 9 & 8 & 9 \\
\hline $\begin{array}{c}\text { Permanence time of the } \\
\text { participants }\end{array}$ & high & high & high & high & high \\
\hline Biological diversity & 25 & 45 & 38 & 18 & $65^{b}$ \\
\hline Land tenure security & medium & high & high & high & high \\
\hline Activities diversification & 3 & 0 & 5 & 1 & $5^{a}$ \\
\hline Present ecotechnologies & 5 & 3 & 4 & 0 & $6^{a}$ \\
\hline $\begin{array}{l}\text { Generation and transmission } \\
\text { of knowledge }\end{array}$ & low & high & high & low & high \\
\hline $\begin{array}{c}\text { Accessibility (space, people } \\
\text { diversity, economic) }\end{array}$ & high & high & medium & low & high \\
\hline Supplies independence & high & medium & high & low & high \\
\hline Safety practices & 100 & 100 & 50 & 50 & 100 \\
\hline
\end{tabular}

The following response to one of the interviews expresses some health benefits perceived by the person interviewed: "People are beginning to come and have found a way to remove stress" (Huerto Tlatelolco). We identified the benefits of reconnecting with nature in responses such as the following one:

"Yes, the best thing about this is contact with the earth and what that gives you in a state of mind" (Ectagono); "I think contacting the earth gives you back that human feeling, that we come from the earth and we are from the earth" (Huerto Tlatelolco).

The indicator of the permanence of the participants expressed through the responses of the interviewees in which the taste for their work or participation in the garden, as well as the frequency and length of their involvement with space. For example, the following response: 
"Well, they are constant (the volunteers), for example, look at the lady who is there watering, she comes every eight days because she lives a bit far. The one who has plot 13 comes two times a week, too, he's is an old man" (Garden of the Girls and Boys).

Regarding the indicator of the security of land tenure, some interviewees mentioned difficulties because the land belongs to the government, as the following quote shows:

"About 2 or 3 administrations ago, I really don't remember well. The point is that they began to have many, many obstacles, they took the light off, and they began to put many obstacles to teach in workshops" (Huerto Romita).

We identified the generation and transmission of knowledge, since the participants mentioned doing different tests or experiments with their crops, as well as university students who research the gardens as expressed by persons below:

“... each one of us sows what we want by and to experiment, to learn" (Huerto Romita);

"There is a boy from the UAM Xochimilco (Metropolitan Autonomous University), who is doing the same research on all the orchards ... but he focuses more on the socio-cultural development in the gardens... " (Huerto Lincoln).

"I occupy it (the garden) as an educational area for my son ... usually in the afternoons is when I come with him and teach him everything that has to do with plants ... I even get out of here to teach him mathematics ... " (Composteros Tlatelolco).

Finally, a necessary process is that which refers to accessibility, which, in turn, includes economic openness, referring to the fact that the products and services offered are affordable; also accessibility to space, that is to say to the garden itself; and finally, accessibility in terms of diversity of people, that is, there are no restrictions due to age, gender, or economic situation, among others. The foregoing was identified in expressions such as the following:

"For our courses, we always give access to three people who can enter for free as scholarship recipients by the exchange of hours" (Ectagono); "Here is a public place open to all people" (Huerto de las Niña y los Niños).

Subsequently, the information from the interviews, with the help of coding, was synthesized qualitatively and quantitatively according to the nature of each indicator, as shown in Table 4. The purpose of this is to visualize the values obtained since, in the following section (integration of results), the unified indicators are presented on a scale from 0 to 100, including the qualitative ones. The last column serves as a reference to know the behavior of each indicator in the different types of orchards according to the management and regarding the maximum score obtained. It can be seen that there are some indicators in which the difference between categories is higher, for example, in terms of the diversification of indicators or the eco-technologies present.

Table 4. Results of the evaluation of the indicators for the four types of UCG. The graph amoeba allows us to identify which aspects can be improved to achieve a higher level of sustainability, as well as to compare the general behavior of the types of gardens. Scores from 0 to 25 represent low levels of sustainability indicators concerning the essential aspects to be addressed. Those from 50 to 75 indicate intermediate levels of sustainability and elements that need to be improved. Indicators above 75 express an adequate or high level of the indicator that contributes to the sustainability of the system.

There are indicators in which the four categories behave similarly, as is the case of the identified benefits or the time of belonging of the participants. So, regardless of the type of management that the orchards have, those aspects do not change. These last indicators (benefits identified and time of permanence) are related, since the fact of providing benefits can be one of the causes that strengthen the continuity over time of the people involved with these systems. 
"I like this job, I feel good because I don't even remember my illnesses ... for me, this is life, for me this is healthy, it is a pleasant environment" (Huerto de las Niñascas y Niños).

The safety practices indicator shows the need to attend to possible sources of contamination in the four categories, which refer to proximity to highly trafficked avenues (possibility of absorption of heavy metals) and water quality. Regarding the independence of inputs, three types of present contributions to sustainability are: They produce their inputs within the garden, through the elaboration of their compost, use strategies such as the selection of plants for seed production, and use rainwater harvesting systems to cover irrigation, among others.

The diversification of activities is an indicator that shows differences between the established categories of gardens; this refers mainly to the operations through which the people who are part of the system obtain their income. Government gardens and private institutions are the ones with the lowest level in this indicator. The preceding, because both have a fixed budget for their maintenance; however, at the same time, it makes them dependent on a single source of income.

Governmental gardens and those of companies are the ones with the best performance in the indicator of generation and transmission of knowledge. Company gardens are primarily devoted to workshops, and governmental gardens have the main objective of teaching people to grow food. On the other hand, the indicator of eco-technologies shows a medium to a high level in three of the garden categories (civil association, government, and company) and a low level in the gardens of private institutions. The other is because of availability and type of space, since it could become difficult to install specific types of eco-technologies on rooftops. Another possible reason is that the members of the same institution do not attend part of the gardens of private institutions. As it has a low interaction with the garden, it is logical that there is no interest in having additional elements, in this case, eco-technologies. On the other hand, the value of this indicator is related to the knowledge transmission indicators. We observed that on many occasions, they serve as an educational tool and are also strongly associated with the independence of inputs.

On the other hand, biological diversity (richness of plant species) differs between the categories. However, all UCGs are polyculture, and the relationship it has with the benefit of incorporating new species into the diet is present. The presence of native species that may be relevant as strategies for the conservation of biocultural diversity in cities is less clear. In terms of security in land tenure, it is the orchards managed by civil associations that have the lowest level of sustainability. The above, because they are on land belonging to the government, and this entity does not offer them the security of permanence. Finally, Figure 4 shows that the accessibility indicator behaves differently in each of the categories, with government gardens and civil associations being the most accessible. To a large extent, this is because, in both types, the gardens are publicly available and offer most (or all) of their activities for free. 


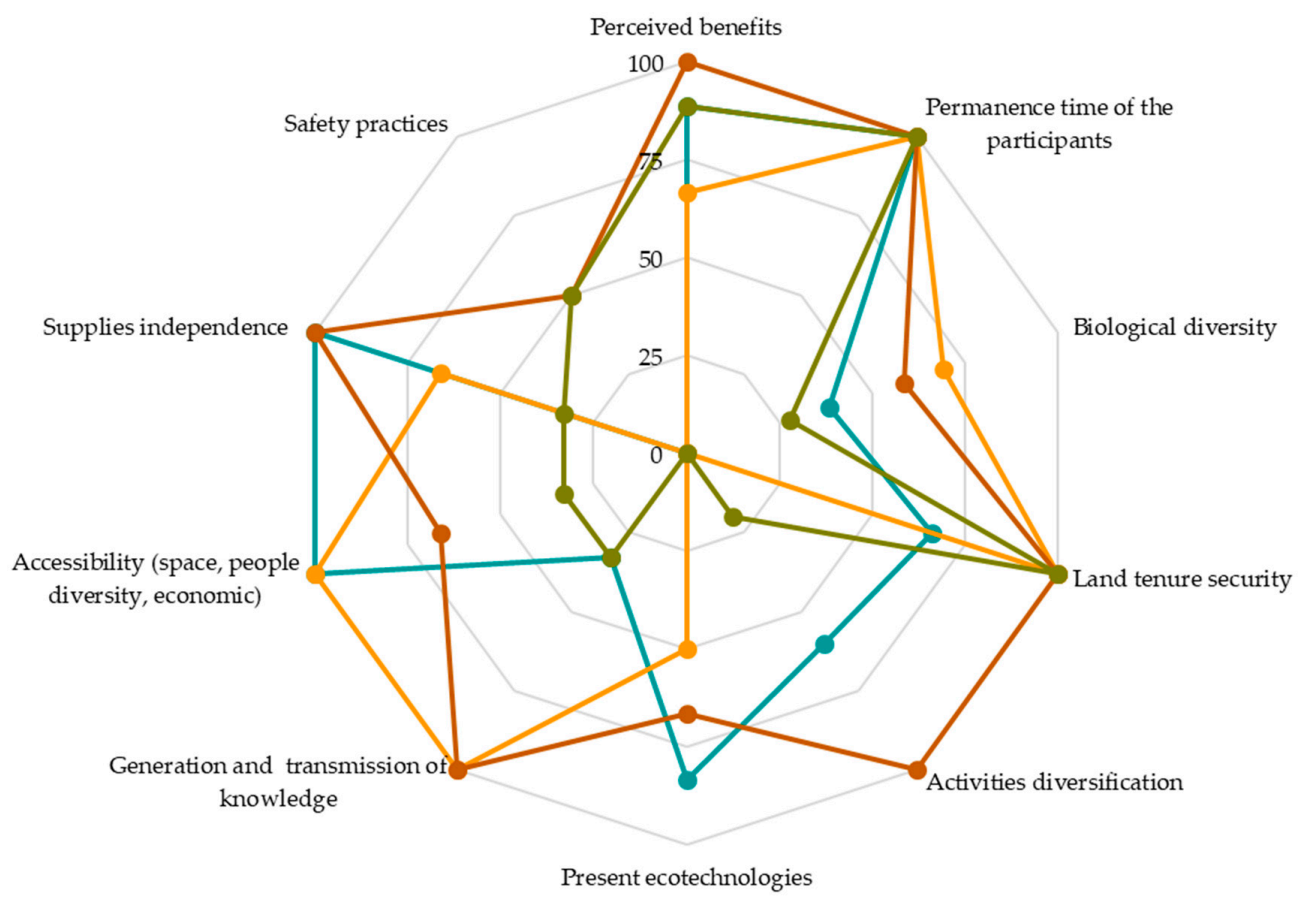

$\multimap$ Civil association $\longrightarrow$ Governamental $\rightarrow$ Company $\rightarrow$ Private institution

Figure 4. Integration of indicators by type. We showed an axis with values from 0 to 100 , representing lower and higher sustainability, respectively. Some indicators behave similarly, regardless of the type, for example, the perceived benefits of the permanence time of the participants. Indicators as the supplies independence or present eco-technologies present medium to high levels. In contrast, the indicator of safety practices shows that it is necessary to attend to it due to the low levels of sustainability it presents. Some indicators behave differently across all indicators, as is the case of accessibility.

\section{Discussion}

1. The aims of the UCG in Mexico City are multiple. The social and economic (local) context in which are found UCG shaped their principal objectives: Education and knowledge transmission processes, promotion or dissemination of environmental issues, and the recovery or appropriation of public spaces. The type of management influenced differs from gardens in other countries. The UCGs were not identified as a recreational or leisure space, as occurs in European countries such as Switzerland or Germany, where they are the main objectives $[26,43,68]$. It is probably related to the economy of the nations, and this influences the priorities of people in cities. That also differs from Latin American countries, since they do not have a subsistence or food security approach. This fact may be because this type of UAP in Mexico City did not arise from an economic or food crisis, as was the case in Argentina or Cuba [69], since the emergence of evaluated experiences is related to the earthquake that occurred in 1985. CdMx has other expressions of UAP that are different from those addressed in this research. UCGs differ from the chinampas and home gardens from the objectives (mainly productive), organization, size, and location of the systems (they are usually in the peri-urban area). Gardens evaluated to respond to the needs and problems of their context, in which there is no need to produce food to survive, which reflects the socioeconomic inequalities among sectors and areas of the city. Collective gardens found in municipalities are classified as urban and non-agricultural, as well as being in a part of the City in which there is more significant and better access to goods and services.

2. Fewer relationships less sustainability. We identified no marked differences between categories regarding agroecological management practices. The main differences are in the interactions with the outside world, and it is relevant to observe the behavior of each type, since these interactions 
can strengthen or weaken the system. In economic or social aspects, the interaction with other actors can generate income, exchange of experiences, as well as support for facilities in terms of land tenure security. Regardless of the direction of interactions, the benefits can be social, economic, or material. We observed that the UCGs managed by private institutions are the ones with the least interactions. At the same time, they obtained low levels of sustainability in most of the indicators, because these UCGs have no function other than adding "value" to space.

3. Tenure land secure and public access as critical point for UCG sustainability in Mexico City. We discussed the results of the evaluation of the indicators in contrast to other studies. In the academic literature, the independence of inputs is a critical factor for the sustainability of UCG $[16,46,70]$. In this sense, the collective gardens of Mexico City show adequate behavior, having medium to high levels of independence. In the literature, insecurity in land tenure is one of the main threats to the permanence of urban collective gardens $[13,24,26,46]$, which could be confirmed in the evaluated UCG, since those managed by civil associations are the most vulnerable. For a better level of sustainability, access to these spaces should be public [14]. Open access is a factor that encourages or limits the transmission of people's benefits. Two of the four UCG types were identified to comply with this feature (those managed by civil associations and government associations). Despite not being strictly restrictive, private access gardens limit the benefits that these spaces provide a smaller number of people.

4. Water safety and contamination are risk factors. Regarding the risk factors for cultivating in the City, a series of safety practices are mentioned in the literature [13]. We identified risk factors like proximity to ample avenues and water quality risks; both did not register in scientific research. In scientific research, little is mentioned regarding eco-technologies present in collective gardens and only speaks of rainwater harvesting systems [25,43,70]. In this study, we identified a greater diversity of eco-technologies. These have the potential to address some of the significant problems identified, such as the problem of water supply in some UCGs, waste management, or wastewater treatment. The lack of interest on the part of the citizens, as well as the deficient participation, are also challenges for the UCGs [14]. We observed that people who receive remuneration for their work tend to stay on overtime.

\subsection{UCG Contributions to the Sustainability (Local) of Mexico City}

One of the most important contributions of gardens to citizens is their relation to the food production system, particularly the health and environmental implications of consumer choices of food. Miguel Escalona [71], considers that this process of transmission of knowledge and reflection is a facilitator to achieve social change. The gardens also function as a tool to disseminate sustainable food production practices, it is accessible information, and it allows for the restoration or maintaining of knowledge lost in cities.

Different studies indicate that one of the advantages of UCGs for the sustainability of cities is that they involve various social actors [72,73], which is essential since they do not work in isolation. In collective gardens of Mexico City, the interactions with other actors vary according to the different categories, but in general, they are weak. We did not even register strong interactions between the diverse experiences of UCGs in the CdMX.

These types of experiences are relevant because it is difficult for cities to be sustainable [74], and these are a means of transmitting information and making visible problems of which citizens are not usually aware. The above, considering that awareness contributes to the positive change of habits.

Returning to the definition of a sustainable city used by Vásquez-Moreno and Córdova [28], the UCGs promote sustainable lifestyles, allowing equitable access to natural and socially constructed well-being, use environmentally friendly alternative technologies, and are spaces that promote environmental conservation.

In addition, they also act on some of the negative environmental implications of the cities, such as the high production of waste, since all UCGs evaluated produce their own compost, and some process 
the neighbors' garbage. Although the gardens do not have the capacity to process all the organic waste produced in the city, they do teach people to do so, in addition to the fact that in existing gardens, they could expand their production of compost by receiving waste from community members. Another consequence of cities is the modification of flora and fauna. Although it was not studied in-depth, urban collective gardens are a way of reinserting nature into cities, which makes them maintenance areas for these beings alive. Finally, cities cause the creation of heat islands, and orchards (and vegetation in general) act as a temperature regulator.

One of the main implications of the influence of urbanization on the food system is the disconnection between said system and citizens. This study shows that UCGs can (re)build this connection, since people generate information and transmit it on the production and origin of the food; few gardens address the preparation and consumption part. Recovering the connection between people and the sources and processes determining production of their food also allows for connecting people with nature, which generates mental well-being in a large city of accelerated rhythms of life. Due to the diversity of species, it is possible to find products that are not in conventional markets, and management of UCGs do not transport products from gardens over long distances. Finally, the integration of native species is a pending issue in the urban experiences of the CDMX.

\subsection{Implications and Future Research}

This type of research can provide elements to justify the importance of these projects remaining since they contain essential benefits. With the above, we consider necessary political support to the Law of Urban Gardens of Mexico City, which supports that lands within the city are destined for this type of project and that the government ensures land tenure. At the same time, the spaces are worked and maintained. This type of governmental support has already been successfully tested in England; however, it would be necessary to delve into the implications and adaptations for the case of Mexico City, since the context is vastly different [51].

Currently, the Ministry of the Environment (SEMARNAT) has a plan to promote and recover green areas within the City, mainly on ridges and avenues [75], and this could also be done through the implementation of UCGs. There is a collective garden with these characteristics that demonstrates the viability of it (Huerto de las Niñas y los Niños) since, in the same way, it is necessary to hire personnel for the maintenance of green areas. In turn, it is considered that this type of garden can be used as a tool to combat problems of social inequality, such as access to sustainable food, as well as a means to reintroduce flora and fauna to the city [7].

Aspects that were not considered in this study, but that are worth addressing in future research, are the following: Number of annual visitors to the UCGs, number of attendees at workshops taught by their managers, tours or other educational activities, quantification of expenses and income that are generated in its maintenance and production, in addition to incorporating different types of values, perception of the neighbors about their benefits, costs, organizational and technological needs, and flora and fauna sampling, among others. On the other hand, a study is proposed that quantifies the potential spaces for the implementation of orchards, for example, those that are deteriorated or in disuse. Additionally, it is pertinent to delve into the identified risk factors, performing water and soil analyses, as well as evaluations of substantial metal absorption due to the proximity to highly trafficked avenues [76]. Finally, it would be interesting to compare the behavior of community gardens in cities with different population and geographic dimensions.

\subsection{Contributions and Limitations of the Study}

We proposed that some indicators can be evaluated with more specific methods, for example, the case of biodiversity from vegetation and fauna sampling. It is worth mentioning that the research was carried out qualitatively since there was no prior information on this type of urban collective garden in Mexico City. However, in future research, it is considered pertinent to delve into the aspects mentioned in the previous section, combining relevant qualitative and quantitative approaches. 
One of the most important contributions of the study is that it allows us to understand the processes necessary to obtain benefits from this type of system, as well as to show processes and elements relevant to the sustainability of the orchards, but also for the benefits or contributions to the city. Part of the advantages of the methodology used is the fact that the indicators are derived specifically for the context under study, which allows us to talk about aspects that are relevant to the specific context of Mexico City and that perhaps are not being used-evaluated in other settings. Additionally, the indicators used to allow us to visualize the processes generated by the UCGs of this city, which are of a social, ecological, economic, and health nature, and coincide with that reported in the literature regarding integrating these dimensions to favor sustainability $[76,77]$.

\section{Conclusions}

The UCGs contribute to the sustainability of Mexico City through generating benefits and processes in all the dimensions of sustainability analyzed:

(1) In the ecological dimension, eco-technologies add to the use of underused resources, in addition to generating educational processes. Having different production destinations makes healthy products available to different people in different environments, inside and outside the orchards. Agroecological practices are an alternative to the inputs used in conventional agriculture, which have a more significant environmental impact; additionally, it promotes reflection processes regarding the ecological impact of conventional agriculture.

(2) In the social dimension, depending on the category, the benefits and processes generated are socially and economically accessible. They are spaces that create and transmit knowledge in different areas, in addition to making people aware of environmental issues, mainly regarding the food system. It offers citizens spaces for social interaction and contact with nature. It allows people to learn about the agricultural cycle in a practical and free way through volunteering. Additionally, they are spaces that generate jobs and therapeutic benefits for citizens.

(3) In the technological dimension, the UCG also promote the processing of organic waste, in addition to training people to do so, which responds to one of the biggest problems in cities, which is the generation of waste. It reinserts nature in cities, maintaining flora and fauna, in addition to regulating temperature. Additionally, they generate processes to reconnect people with their food and, in general, with the food system and nature.

This research shows the aspects in which the UCG contribute to the local sustainability of Mexico City. By knowing these aspects, the information is useful to enhance the gardens, replicate them, make them visible, and improve them. Likewise, it makes visible aspects that can be enhanced to improve the level of sustainability of the gardens themselves. Finally, the information obtained is potentially useful as a basis for participating in a public policy design process for Mexico City.

Author Contributions: K.G.F. is bachelor from Escuela Nacional de Estudios Superiores UNAM. A.I.M.-C. is a researcher at the Escuela Nacional de Estudios Superiores Unidad Morelia, UNAM, Morelia. J.B. is researcher at the Centro de Investigación en Biodiversidad y Conservación (CIByC), Morelos. A.C. is a researcher at Instituto de Investigaciones en Ecosistemas y Sustentabilidad, UNAM, and drafted and reviewed the manuscript. K.G.F. and A.I.M.-C. did all the research design as part of her bachelor program activities from the first author K.G.F. K.G.F. did systematization, data analysis, and writing this paper. A.I.M.-C. is the bachelor thesis director and wrote this document with K.G.F., J.B., and A.C. are experts in sustainable management of socioecosystems and reviewed, commented, and improve the manuscript. All authors have read and agreed to the published version of the manuscript.

Funding: The authors acknowledges to the DGAPA-UNAM for supporting the PAPIIT UNAM IG200720 project.

Acknowledgments: The authors thank the UCG participants for their participation in this research.

Conflicts of Interest: The authors declare no conflict of interest. 


\section{Appendix A}

Table A1. General characteristics and brief historical description of the evaluated gardens.

\begin{tabular}{|c|c|c|c|c|c|}
\hline Category & $\begin{array}{l}\text { Urban and Periuban } \\
\text { Collective Gardens }\end{array}$ & $\begin{array}{c}\text { Year of } \\
\text { Foundation }\end{array}$ & Location & $\begin{array}{l}\text { Estimated } \\
\text { Area }\left(m^{2}\right)\end{array}$ & Historical Description \\
\hline \multirow{4}{*}{ Civil association } & Huerto Roma Verde & 2012 & Cuauhtémoc & 1361 & $\begin{array}{l}\text { The } 1985 \text { earthquake damaged a building. The building was } \\
\text { demolished and space became a garbage dump. The land was } \\
\text { recovered by a civil association with the help of the neighbors. }\end{array}$ \\
\hline & Huerto Tlatelolco & 2012 & Cuauhtémoc & 1521 & $\begin{array}{l}\text { The UCG is located on a land where there was a building, which was } \\
\text { demolished because of the damages caused by the } 1985 \text { earthquake. }\end{array}$ \\
\hline & Composteros Tlatelolco & 2015 & Cuauhtémoc & 672 & $\begin{array}{l}\text { Space where there was a building that was damaged by the } 1985 \\
\text { earthquake. The land was recovered by a community composting } \\
\text { project by the UNAM and the Goethe-Institut Mexiko. In 2015, } \\
\text { the project ended and was left in the hands of the neighbors } \\
\text { involved, later they decided to start growing food. }\end{array}$ \\
\hline & Huerto Romita & 2007 & Cuauhtémoc & 79 & $\begin{array}{c}\text { Founded by the civil association "Sembradores Urbanos" in a space } \\
\text { donated by the government }\end{array}$ \\
\hline \multirow{4}{*}{ Governmental } & Centro Verde Azcapotzalco & 2011 & Azcapotzalco & 1220 & Government initiative to teach citizens to produce food. \\
\hline & ESPIGA & 2018 & Iztacalco & 4774 & Government space to promote healthy eating. \\
\hline & $\begin{array}{l}\text { Huerto de las niñas y los } \\
\text { niños }\end{array}$ & 2016 & Cuauhtémoc & 4711.8 & $\begin{array}{l}\text { Located on a median surrounded by heavily traveled avenues. } \\
30 \text { years ago, the land had fruit trees, but the allotments and the } \\
\text { volunteer program had been incorporated } 3 \text { years ago. }\end{array}$ \\
\hline & Huerto Lincoln & 2017 & Miguel Hidalgo & 383 & $\begin{array}{l}\text { In 2013, the government decided to implement a UGC; in 2016, it was } \\
\text { abandoned and became a garbage dump. People reactivated the } \\
\text { space two years ago. }\end{array}$ \\
\hline
\end{tabular}


Table A1. Cont.

\begin{tabular}{|c|c|c|c|c|c|}
\hline Category & $\begin{array}{l}\text { Urban and Periuban } \\
\text { Collective Gardens }\end{array}$ & $\begin{array}{l}\text { Year of } \\
\text { Foundation }\end{array}$ & Location & $\begin{array}{l}\text { Estimated } \\
\text { Area }\left(m^{2}\right)\end{array}$ & Historical Description \\
\hline \multirow{7}{*}{ Company } & Ectagono & 2015 & Álvaro Obregón & 5068 & $\begin{array}{l}\text { Place where various environmental initiatives converge, and the } \\
\text { garden is one of them. The founder decided to establish a garden in } \\
\text { search of mental well-being. }\end{array}$ \\
\hline & Casa Delta & 2018 & Cuauhtémoc & 243.6 & $\begin{array}{l}\text { The founder has } 15 \text { years of experience in AU and agroecology. } \\
\text { He teamed up with a chef to establish the garden in his restaurant. }\end{array}$ \\
\hline & $\begin{array}{l}\text { Huerto Casa Club del } \\
\text { Académico }\end{array}$ & 2016 & Coyoacán & 1037 & $\begin{array}{l}\text { It started as a proposal from the person in charge of maintaining a } \\
\text { green wall in the restaurant. Currently, the production is for the } \\
\text { restaurant, and the tour of the garden is part of the customer } \\
\text { experience. }\end{array}$ \\
\hline & Huerto Los Cedros & 2007 & $\begin{array}{l}\text { Magdalena } \\
\text { Contreras }\end{array}$ & 34539 & $\begin{array}{l}\text { Space that has been inherited for generations. They used to grow } \\
\text { maize for their own consumption; } 13 \text { years ago, they began to market } \\
\text { organic vegetables. }\end{array}$ \\
\hline & ISLA & 2014 & Miguel Hidalgo & 293 & $\begin{array}{l}\text { The owners of the company got involved with the theme of the } \\
\text { gardens for a healthy eating issue. }\end{array}$ \\
\hline & Heirloom & 2014 & Cuauhtémoc & 570 & $\begin{array}{c}\text { The company dedicated to implementing gardens and offering } \\
\text { workshops. The founder studied agroecology and grew up in an } \\
\text { urban/rural environment. }\end{array}$ \\
\hline & Huertos Concretos & 2015 & Cuauhtémoc & 625 & $\begin{array}{c}\text { Its founder is one of the pioneers in UCG in Mexico City. } \\
\text { Her company is dedicated to giving workshops and implementing } \\
\text { urban and rural agriculture projects. }\end{array}$ \\
\hline \multirow{4}{*}{$\begin{array}{l}\text { Private } \\
\text { institution }\end{array}$} & Huerto IBERO & 2018 & Álvaro Obregón & 62 & Student initiative in collaboration with the architecture department. \\
\hline & Hospital ABC Observatorio & 2017 & Álvaro Obregón & 350 & $\begin{array}{l}\text { UCG implemented with the interest of generating added value to } \\
\text { the hospital. }\end{array}$ \\
\hline & Hospital ABC Santa Fe & 2017 & Cuajimalpa & 339 & $\begin{array}{c}\text { UCG implemented with the interest of generating added value to } \\
\text { the hospital. }\end{array}$ \\
\hline & $\begin{array}{l}\text { Huerto Fundación San } \\
\text { Felipe de Jesús }\end{array}$ & 2016 & Miguel Hidalgo & 134 & $\begin{array}{l}\text { They decided to implement the UCG as an educational strategy for } \\
\text { vulnerable girls and boys, since the area is prone to drug addiction } \\
\text { and vandalism problems. }\end{array}$ \\
\hline
\end{tabular}




\section{References}

1. MacLaren, V.W. Urban Sustainability Reporting. J. Am. Plan. Assoc. 1996, 62, 184-202. [CrossRef]

2. De la Fuente, P. Construyendo Soberanía Alimentaria Desde la Ciudad: Madrid, Una Mirada Agroecológica. Master's Thesis, Universidad Internacional de Andalucía, Madrid, Spain, 2012.

3. Mahiques, J. Los huertos urbanos: Buena praxis en sostenibilidad urbana. In Profesionales y Herramientas Para el Desarrollo Local y Sus Sinergias Territoriales: Evaluación y Propuestas de Futuro, 1st ed.; Martínez, A., Montesinos, X., Sancho, I., Sanchiz, D., Eds.; Universitat D’Alacant: San Vicente del Raspeig, Spain, 2016; pp. 719-735.

4. Morán, N. Huertos y jardines comunitarios. Boletín CF+S 2008, 40, 87-100.

5. Pakzad, P.; Osmond, P. Corrigendum to Developing a Sustainability Indicator Set for Measuring Green Infrastructure Performance. Procedia Soc. Behav. Sci. 2016, 216, 1006. [CrossRef]

6. Pisanty, I.; Mazari, M.; Ezcurra, E. El reto de la conservación de la biodiversidad en zonas urbanas y periurbanas. Capital Natural México 2009, 2, 719-759.

7. Ghosh, S. Measuring sustainability performance of local food production in home gardens. Local Environ. 2012, 19, 33-55. [CrossRef]

8. Lin, B.; Philpott, S.M.; Jha, S. The future of urban agriculture and biodiversity-ecosystem services: Challenges and next steps. Basic Appl. Ecol. 2015, 16, 189-201. [CrossRef]

9. Zhang, L.; Xu, Y.; Yeh, C.H.; Liu, Y.; Zhou, D. City sustainability evaluation using multi-criteria decision making with objective weights of interdependent criteria. J. Clean. Prod. 2016, 131, 491-499. [CrossRef]

10. Jenks, M.; Jones, C. Issues and concepts. In Dimensions of the Sustainable City; Jenks, M., Jones, C., Eds.; Springer: Dordrecht, The Netherlands, 2010; Volume 2, pp. 1-19.

11. Chiesura, A. The role of urban parks for the sustainable city. Landsc. Urban Plan. 2004, 68, 129-138. [CrossRef]

12. Haughton, G. Environmental Justice and the Sustainable City. J. Plan. Educ. Res. 1999, 18, 233-243. [CrossRef]

13. Armar-Klemesu, M. Urban agricultura and food security, nutrition and health. In Growing Cities, Growing Food: Urban Agriculture on the Policy Agenda; A reader on urban agriculture; Bakker, N., Dubbeling, M., Gundel, S., Sabel-Koschella, U., de Zeeuw, H., Eds.; German Foundation for International Development: Feldafing, Germany, 2000; pp. 99-117.

14. Beilin, R.; Hunter, A. Co-constructing the sustainable city: How indicators help us "grow" more than just food in community gardens. Local Environ. 2011, 16, 523-538. [CrossRef]

15. Feenstra, G. Creating space for sustainable food systems: Lessons from the field. Agric. Hum. Values 2002, 19, 99-106. [CrossRef]

16. Holguín, C. Agricultura Urbana en Quito: Estudio Comparativo de los Beneficios y Perspectivas de la Agricultura Urbana en Cuatro Barrios de la Ciudad de Quito. Bachelor's Thesis, Universidad San Francisco de Quito, Quito, Ecuador, 2015.

17. Turner, B. Embodied connections: Sustainability, food systems and community gardens. Local Environ. 2011, 16, 509-522. [CrossRef]

18. Pothukuchi, K. Community Food Assessment. J. Plan. Educ. Res. 2004, 23, 356-377. [CrossRef]

19. Cloutier, S.; Jambeck, J.; Scott, N. The Sustainable Neighborhoods for Happiness Index (SNHI): A metric for assessing a community's sustainability and potential influence on happiness. Ecol. Indic. 2014, 40, 147-152. [CrossRef]

20. Kingsley, J.Y.; Townsend, M.; Henderson-Wilson, C. Cultivating health and wellbeing: Members' perceptions of the health benefits of a Port Melbourne community garden. Leis. Stud. 2009, 28, 207-219. [CrossRef]

21. Mercon, J.; Escalona-Aguilar, M.Á. Cultivando la Educación Agroecológica: El huerto colectivo urbano como espacio educativo. Rev. Mex. Investig. Educ. 2012, 17, 1201-1224.

22. Saldías, G. Huerta urbana comunitaria, una buena práctica social. Revista Diseño Urbano Y Paisaje 2016, 31, 54-61.

23. Bellenda, B. Huertas en Montevideo: Agricultura urbana "a la uruguaya". LEISA Rev. De Agroecol. 2005, 21, 29-32.

24. Bilxen, C.; Colnago, P.; González, N.; Márquez, C.; Chiappe, M. Indicadores de sustentabilidad para la agricultura urbana. In Proceedings of the Seminario de Cooperación y Desarrollo en Espacios Rurales Iberoamericanos: Sostenibilidad e Indicadores, Almeria, Spain, 16-17 October 2007. 
25. Clavijo, C.; Cuvi, N. La sustentabilidad de las huertas urbanas y periurbanas con base agroecológica: El caso de Quito. Letras Verdes Rev. Latinoam. Estud. Socioambientales 2017, 14, $27-47$.

26. Holland, L. Diversity and connections in community gardens: A contribution to local sustainability. Local Environ. 2004, 9, 285-305. [CrossRef]

27. Soler, M.; Rivera, M. Agricultura urbana, sostenibilidad y soberanía alimentaria: Hacia una propuesta de indicadores desde la agroecología. In Proceedings of the Décimo Congreso Español de Sociología, Pamplona, Spain, 1-3 July 2007.

28. Vásquez-Moreno, L.; Vázquez, A.C.Y. A conceptual framework to assess urban agriculture's potential contributions to urban sustainability: An application to San Cristobal de Las Casas, Mexico. Int. J. Urban Sustain. Dev. 2013, 5, 200-224. [CrossRef]

29. Evers, A.; Hodgson, N.L. Food choices and local food access among Perth's community gardeners. Local Environ. 2011, 16, 585-602. [CrossRef]

30. Schram-Bijkerk, D.; Otte, P.; Dirven, L.; Breure, A.M. Indicators to support healthy urban gardening in urban management. Sci. Total. Environ. 2018, 621, 863-871. [CrossRef]

31. Pearson, L.J.; Pearson, L.; Pearson, C.J. Sustainable urban agriculture: Stocktake and opportunities. Int. J. Agric. Sustain. 2010, 8, 7-19. [CrossRef]

32. Ferris, J.; Norman, C.; Sempik, J. People, Land and Sustainability: Community Gardens and the Social Dimension of Sustainable Development. Soc. Policy Adm. 2001, 35, 559-568. [CrossRef]

33. Drescher, A.W.; Holmer, R.J.; Iaquinta, D.L. Urban Homegardens and Allotment Gardens for Sustainable LiveliHoods: Management Strategies and Institutional Environments. In Tropical Homegardens; Kumar, B., Nair, P., Eds.; Springer: Dordrecht, The Netherlands, 2006; Volume 3, pp. 317-338.

34. Egli, V.; Smith, M.; Tautolo, E.S. The development of a model of community garden benefits to wellbeing. Prev. Med. Rep. 2016, 3, 348-352. [CrossRef] [PubMed]

35. Trendov, N.M. Comparative study on the motivations that drive urban community gardens in Central Eastern Europe. Ann. Agrar. Sci. 2018, 16, 85-89. [CrossRef]

36. Causse, M. El concepto de comunidad desde el punto de vista socio-histórico-cultural y lingüístico. Ciencia en su PC 2009, 3, 12-21.

37. Díaz, F. Comunidad y comunalidad. La Jornada 2004, 12, 365-373. Available online: http://www.insumisos. com/lecturasinsumisas/Comunidad.\%20y\%200comunalidad.pdf (accessed on 14 September 2020).

38. Krause, M. Hacia una redefinición del concepto de comunidad-cuatro ejes para un análisis crítico y una propuesta. Revista Psicología 2001, 2, 49-60. [CrossRef]

39. Maya, I. Sentido de comunidad y potenciación comunitaria. Apuntes Psicología 2004, 22, 187-211.

40. Cameron, R.W.; Blanuša, T.; Taylor, J.E.; Salisbury, A.; Halstead, A.J.; Henricot, B.; Thompson, K. The domestic garden-Its contribution to urban green infrastructure. Urban For. Urban Green. 2012, 11, 129-137. [CrossRef]

41. Codyre, M.; Fraser, E.D.; Landman, K. How does your garden grow? An empirical evaluation of the costs and potential of urban gardening. Urban For. Urban Green. 2015, 14, 72-79. [CrossRef]

42. La Rosa, D.; Barbarossa, L.; Privitera, R.; Martinico, F. Agriculture and the city: A method for sustainable planning of new forms of agriculture in urban contexts. Land Use Policy 2014, 41, 290-303. [CrossRef]

43. Beumer, C. Show me your garden and I will tell you how sustainable you are: Dutch citizens' perspectives on conserving biodiversity and promoting a sustainable urban living environment through domestic gardening. Urban For. Urban Green. 2018, 30, 260-279. [CrossRef]

44. Losada, H.; Vieyra, J.; Pealing, R.; Zavala, R.; Cortés, J. Urban Agriculture in the Metropolitan Zone of Mexico: Changes over time in the sub-urban and peri-urban areas. Environ. Urban. 1998, 10, 37-54. [CrossRef]

45. Soriano, R. Agricultura urbana en la Ciudad de México y su área conurbada: Situación y perspectivas. Agraria Nueva Época 2005, 1, 6-13.

46. Gachuz, S. Huertos Urbanos Comunitarios: Experiencias de Gestión y Agroecología en Ciudades del Norte y Sur Global. Master's Thesis, El Colegio de la Frontera Sur, Chiapas, Mexico, 2015.

47. Masera, O.; Astier, M.; López-Ridaura, S. Sustentabilidad y Manejo de Recursos Naturales; Grupo Interdisciplinario de Tecnología Rural Apropiada: Pátzcuaro, México, 1999.

48. Astier, M.; Hollands, J. Sustentabilidad y Campesinado: Seis Experiencias Agroecológicas en Latinoamérica; Grupo Interdisciplinario de Tecnología Rural Apropiada: Pátzcuaro, Mexico, 2005. 
49. Astier, M.; Galván-Miyoshi, Y.; Masera, O.; García-Barrios, L.; González-Esquivel, C.E. Assessing the Sustainability of Small Farmer Natural Resource Management Systems. A Critical Analysis of the MESMIS Program (1995-2010). Ecol. Soc. 2012, 17. [CrossRef]

50. Speelman, E.N.; López-Ridaura, S.; Colomer, N.A.; Astier, M.; Masera, O.R. Ten years of sustainability evaluation using the MESMIS framework: Lessons learned from its application in 28 Latin American case studies. Int. J. Sustain. Dev. World Ecol. 2007, 14, 345-361. [CrossRef]

51. Torres, P.; Rodríguez, L.; García, B. Mexico City: The integration of urban agriculture to contain urban sprawl. In Growing Cities, Growing Food: Urban Agriculture on the Policy Agenda; A reader on urban agriculture; Bakker, N., Dubbeling, M., Gündel, S., Sabel-Koschella, N., Zeeuw, H., Eds.; Zentralstelle für Ernáhrung und Landwirtschaft: Berlin, Germany, 2000; pp. 363-390.

52. ONU HABITAT. Superficie de CdMx Crece a Ritmo Tres Veces Superior al de su Población. Available online: https://onuhabitat.org.mx/index.php/superficie-de-cdmx-crece-a-ritmo-tres-veces-superior-al-desu-poblacion (accessed on 30 October 2019).

53. INEGI. Encuesta Intercensal. 2015. Available online: https://www.inegi.org.mx/programas/intercensal/2015/ default.html\#Tabulados (accessed on 30 October 2019).

54. Chávez, A.; Palacios, J. Importancia de los cursos de agricultura urbana ante el cambio climático y la seguridad alimentaria en México. Rev. DELOS Desarro. Local Sosten. 2017, 10, 28.

55. Pérez, M.D.P.P.; Ávila, A.E.R.; Torres, A.S.M. Evaluación de la sustentabilidad: Una reflexión a partir del caso de la Red Nacional de Desarrollo Rural Sustentable (México). Entreciencias Diálogos Soc. Conoc. 2016, 4, 61-72.

56. ALDF. Ley de Huertos Urbanos en la Ciudad de México. Available online: http://www.aldf.gob.mx/archivo2f67938c69ef3a4c7270705a3522b187.pdf (accessed on 15 May 2019).

57. ALDF. Ley de Huertos Urbanos de la CdMx, Clave Para la Seguridad Alimentaria y Cuidado del Medio Ambiente. Available online: http://www.aldf.gob.mx/comsoc-ley-huertos-urbanos-cdmx-clave-seguridadalimentaria-y-cuidado-medio-ambiente--28587.html (accessed on 15 May 2019).

58. Pérez, G.; Delgado, R.; Bernal, L. Agricultura urbana: Una alternativa sustentable para el desarrollo regional. In Proceedings of the Vigésimo primer Encuentro Nacional Sobre Desarrollo Regional en México, Mérida, México, 15-18 November 2016; pp. 1-20.

59. Martín-Crespo, C.; Salamanca, A. El Muestreo en la Investigación Cualitativa. Available online: http: //www.sc.ehu.es/plwlumuj/ebalECTS/praktikak/muestreo.pdf (accessed on 30 October 2019).

60. Clavijo, C. La Agricultura Urbana en Quito: Análisis de la Sustentabilidad de las Huertas de Tres Proyectos. Master's Thesis, Facultad Latinoamericana de Ciencias Sociales, Quito, Ecuador, 2013.

61. Strauss, A.; Corbin, J. Bases de la Investigación Cualitativa: Técnicas y Procedimientos Para Desarrollar la Teoría Fundamentada; Sage Publications: Antioquia, Colombia, 2002.

62. Bernard, R. Research Methods in Anthropology: Qualitative and Quantitative Approaches, 4th ed.; AltaMira Press, Rowman \& Littlefield: Lanham, MD, USA, 2006.

63. Tarrés, M. Observar, Escuchar y Comprender, 1st ed.; Facultad Latinoamericana de Ciencias Sociales: Mexico City, Mexico, 2001.

64. Martín, D. Teoría fundamentada y Atlas.ti: Recursos metodológicos para la investigación educativa. Rev. Electrónica Investig. Educ. 2014, 16, 104-122.

65. Corkery, L. Community Gardens as a Platform for Education for Sustainability. Aust. J. Environ. Educ. 2004, 20, 69-75. [CrossRef]

66. Richter, F.; Cuenca, J. El cultivo de sí. La agricultura urbana desde la experiencia del ocio. In Federación Española de Sociología; Comunicación al X Congreso Español de Sociología: Madrid, Spain, 2015.

67. Tappert, S.; Klöti, T.; Drilling, M. Contested urban green spaces in the compact city: The (re-)negotiation of urban gardening in Swiss cities. Landsc. Urban Plan. 2018, 170, 69-78. [CrossRef]

68. Gómez, J. Agricultura Urbana en América Latina y Colombia: Perspectivas y Elementos Agronómicos Diferenciadores. Bachelor's Thesis, Universidad Nacional Abierta y a Distancia, Boyacá, Colombia, 2014.

69. Alvarado, E. Agroecología y Autogestión en la Ciudad. Una Mirada Desde Dos Experiencias de Agricultura Urbana en la Zona Metropolitana de Guadalajara, México. Master's Thesis, Universidad Internacional de Andalucía, Sevilla, Spain, 2015. 
70. Escalona, M.; Ábato, M.; Castillo, D.; Reyes, N.; y Domínguez, N. Aprendizajes y colectividades desde la agricultura urbana y periurbana. In Proceedings of the Primer Congreso Mexicano de Agroecología, San Cristóbal de las Casas, México, 12-17 May 2019. Available online: https://www.ecosur.mx/inauguraciondel-primer-congreso-mexicano-de-agroecologia/ (accessed on 14 September 2020).

71. Cruz, M. La agricultura urbana: ¿Pobreza o desarrollo sustentable? In Agricultura Urbana y Periurbana en México; Zurita, M., Ed.; Universidad Autónoma de Chapingo: Texcoco de Mora, Mexico, 2004; pp. 149-162.

72. Evans, B.; Joas, M.; Sundback, S.; Theobald, K. Governing local sustainability. J. Environ. Plan. Manag. 2006, 49, 849-867. [CrossRef]

73. Jiménez-Osornio, J. Evaluación de un sistema familiar de producción huevo para plato en Tahdziu, Yucatán. In Proceedings of the Primer Congreso Mexicano de Agroecología, San Cristóbal de las Casas, México, 12-17 May 2019.

74. Robles, M. ¿Cómo pueden contribuir las IES en la resolución de los problemas socio ambientales de la ciudad y la construcción de vías para la sustentabilidad? In Proceedings of the Foro Rumbo a la Sostenibilidad de la Ciudad de Mexico: UNAM, Mexico City, Mexico, 31 July-2 August 2019.

75. Sánchez, B. SPR la pomarroza: Una experiencia del proceso de certificación orgánica de la ganadería y la comercialización de queso. In Proceedings of the Primer Congreso Mexicano de Agroecología, San Cristóbal de las Casas, Mexico, 12-17 May 2019.

76. Alberti, M. Measuring urban sustainability. Environ. Impact Assess. Rev. 1996, 16, 381-424. [CrossRef]

77. Bulkeley, H.; Betsill, M. Rethinking Sustainable Cities: Multilevel Governance and the 'Urban' Politics of Climate Change. Environ. Politics 2005, 14, 42-63. [CrossRef]

(C) 2020 by the authors. Licensee MDPI, Basel, Switzerland. This article is an open access article distributed under the terms and conditions of the Creative Commons Attribution (CC BY) license (http://creativecommons.org/licenses/by/4.0/). 